\title{
Can biosolids compost improve, in the short term, native vegetation and soils fertility in burned Nothofagus pumilio forest in Patagonia, Argentina?
}

\author{
¿Puede el compost de biosólidos mejorar a corto plazo la vegetación nativa y las características de \\ fertilidad del suelo en un bosque quemado de Nothofagus pumilio en la Patagonia Argentina?
}

\author{
Santiago A Varela ${ }^{\text {a*}}$, Miriam E Gobbi ${ }^{\text {b }}$, Francisca Laos ${ }^{\mathrm{c}}$ \\ * Corresponding author: ${ }^{a}$ Grupo de Ecología Forestal I.N.T.A. E.E.A. Bariloche, Río Negro, Argentina, \\ tel.: 54-(02944)422731(int. 238), svarela@bariloche.inta.gov.ar \\ ${ }^{\mathrm{b}}$ Universidad Nacional del Comahue, Centro Regional Universitario Bariloche (CRUB), \\ Quintral 1250, C.P. 8400, Bariloche, Argentina. \\ c Universidad Nacional de Río Negro, Villegas 147, C.P. 8400, Bariloche, Argentina.
}

\begin{abstract}
SUMMARY
In the Patagonian Andean forests, wildfires principally have an anthropic origin and constitute one of the most important disturbances. They lead to severe losses of soil fertility and vegetation; particularly compromising the regeneration of native vegetation. Organic amendments can facilitate the regeneration of vegetation, enhancing principally soil fertility conditions. Our objective was to evaluate the effects of biosolids compost application as a tool for recovering soil fertility and regenerating vegetation in burnt areas of a Nothofagus pumilio forest along two growing seasons. Considering the National Park status of the study area, low rates $\left(2 \mathrm{~kg} \mathrm{~m}^{-2}\right)$ of biosolids compost application were used to minimize the polluting effect of this amendment. We considered two types of microsites, with and without litter accumulation, in order to test whether biosolids application had a differential effect related to microsite type. Soil properties, composition and cover vegetation were evaluated. We concluded that biosolids compost application improved some of the physical-chemical, chemical and biological soil properties but did not contribute, over a period of almost two growing seasons, to vegetation recovery. These results confirm that organic amendment application may be used as an initial restoration strategy at microsite level in burnt $N$. pumilio forests related principally to a beneficial effect on soil fertility. The creation of fertility islands can be a valid restoration strategy, but mechanisms to increase the reinstallation of native vegetation should be also applied.
\end{abstract}

Key words: microsite, litter, post-fire regeneration, organic amendments.

\section{RESUMEN}

En los bosques andino patagónicos los incendios de origen antrópico son uno de los principales disturbios. Estos conducen a pérdidas de fertilidad del suelo y de vegetación, y comprometen, particularmente, la regeneración de la vegetación nativa. La aplicación de enmiendas orgánicas podría facilitar la regeneración de dicha vegetación, mejorando principalmente la fertilidad del suelo. El objetivo del presente trabajo fue evaluar los efectos de la aplicación de compost de biosólidos en la recuperación de la fertilidad del suelo y la regeneración de vegetación durante dos estaciones de crecimiento en áreas quemadas de bosque de Nothofagus pumilio. Considerando el estatus de Parque Nacional del área de estudio, la aplicación de compost se realizó en dosis bajas (2 kg m²). Se consideraron micrositios con y sin acumulación de hojarasca, en función de registrar si la aplicación de compost de biosólidos generaba efectos diferenciales por micrositio. Se evaluaron características de fertilidad del suelo, composición y cobertura de especies vegetales luego de la aplicación. El compost de biosólidos mejoró algunas características fisicoquímicas, químicas y biológicas del suelo pero no promovió la recuperación de la cubierta vegetal. Estos resultados confirman que la aplicación de enmiendas orgánicas puede ser utilizada como una estrategia de restauración a nivel de micrositio en bosques quemados de $N$. pumilio, relacionada principalmente con un efecto benéfico en la fertilidad del suelo. La creación de islas de fertilidad puede ser una estrategia de restauración de la vegetación, si se asegura la aplicación de mecanismos para incrementar la reinstalación de especies vegetales nativas.

Palabras clave: micrositio, hojarasca, regeneración post-fuego, enmiendas orgánicas.

\section{INTRODUCTION}

Fire plays a major role in community dynamics and nutrient balance. They have important implications on rates of carbon fixation, nutrient cycling, species composition, plant growth and soil properties and indirectly affect water flow and suppl, and can generate drastic recurrent floods or pe- riods of extreme drought (due to a reduction in plant cover and an increase in soils moisture evaporation by solar radiation), and cause changes in microclimatic conditions. The intensity and duration of fire impacts are determined by the type of fire, soil and vegetation, severity, temperature and frequency, as well as topography, season, pre- and post-fire weather conditions and regional species pool (Tegart 2004). 
In Patagonian Andean region, the current multidecadal trend towards higher temperatures, linked to global anthropogenic warming, is likely to continue to increase the frequency and severity of extreme droughts during the $21^{\text {st }}$ century. These climate trends in combination with the noted land-use changes imply that the large fire events of the late 1990s-2000s may be the initiation of a longer-lasting trend towards increasingly widespread fire with accumulating changes in landscape structure (Veblen et al. 2008).

The number and intensity of fires in Patagonian Andean forests are highly variable, with the greatest events occurring in years of severe drought; records for northwestern Patagonia indicate that about 17,400 ha of forests were burned between 1988 and 1999 (de Torres Curth et al. 2002). Currently, wildfires lead to severe losses of soil fertility and plant cover in the long term (Kitzberger et al. 2005). For other regions in the world, it is know that as a result of long-term losses in rootable soil volume and nutrient availability associated with recurrent fires, pre-fire communities may not establish (Ferran et al. 2005).

Management practices aiming at recovering soil organic matter may increase nutrient availability, water storage capacity, seed bank expression and seedling survival. Addition of organic waste is one of the recommended practices for degraded soils (Martínez et al. 2003). Biosolids compost produced in the Northern Patagonian region, with high organic matter content (50 \%) and slow nutrient release capacity (Mazzarino and Laos 2000), would promote the establishment of "fertility islands" which would enhance both seed bank expression and vegetation regeneration in post-fire areas.

However, organic amendments may have deleterious effects on plant community composition, succession trajectory and can generate an income of exogenous species. The thermophilic phase during the composting process ensures pathogen and weed seed reduction in the amendment; however, studies on the effects on seed viability are scarce. Additionally, in many cases and during the maturity phase, the final product is stored outdoors, exposed to the seed rain from the nearby vegetation. Thus, the beneficial effect of compost application on soil fertility may be reduced by the introduction of viable seeds of exogenous species. This should be specifically observed in order to restore native vegetation in areas within National Parks and Municipal Reserves.

Nothofagus pumilio (Poepp et. Endl.) Krasser (lenga) is one of the most important forest resources in Argentina and Chile (more than three million hectares; Schmidt and Lara 1985). These forests have high ecological value; they represent an important refuge for native species (many of them endemic), are watershed protectors and an important economic resource due to their high quality and quantity of wood.

In northwestern Patagonia, vegetal natural regeneration is conditioned by the marked environmental gradient as well as microsite conditions. The accumulation of litter on microsites near tree trunks might have an effect on seedling survival and development, protecting seedlings from direct solar radiation, providing nutrients through its decomposition; it might facilitate suitable moisture conditions and operate as the principal seed reservoir (Heinemann and Kitzberger 2006, Varela et al. 2006).

Intense fires, particularly in $N$. pumilio forests, have produced long-term changes in soil conditions. Alauzis et al. (2004) found that four years after fire, burnt soils showed no recovery compared to soil in unburnt conditions. The main effects on organic carbon, total nitrogen, extractable phosphorus and microbial biomass were recorded by these and other authors (Diehl et al. 2003, Satti et al. 2003, Kitzberger et al. 2005).

Under post-fire conditions, the lack of natural persistent seed bank, added to the lack of seedlings due to the direct effect of the fire, the inter-annual variable production of seeds, the low resistance of seeds to heat, the absence of resprouting capacity and the unsuitable characteristics of soil fertility, make recolonization by native vegetation difficult. In many cases, these systems are susceptible to replacement by other vegetation (mainly shrubs).

The main goal of this study was to evaluate the effect of biosolids compost on vegetal community composition and soil fertility in the early phases of succession after fire in $N$. pumilio forests. We hypothesised that biosolids compost application on burned soils generates beneficial effects over soils fertility conditions, which depend on microsite conditions, favour native vegetation regeneration and promote exotics establishment.

\section{METHODS}

Study site. The study was conducted in the Challhuaco Valley ( $41^{\circ} 14^{`} \mathrm{~S}$ and $\left.71^{\circ} 17^{`} \mathrm{~W}\right)$, Nahuel Huapi National Park, Argentina. Mean annual precipitation and temperature are $1,200 \mathrm{~mm}$ and $5{ }^{\circ} \mathrm{C}$, respectively (Barros et al. 1983). Soils derived from volcanic ashes and characterized by a high capacity to stabilise organic matter, store water, buffer $\mathrm{pH}$ and retain phosphorus. Nothofagus pumilio forest occurs between 1,000 to 1,600 m asl. Dominant late successional vegetation is typically $N$. pumilio with an understorey of Berberis serrato-dentata Lechler, Maytenus chubutensis (Speg.) Lourt., Ribes magellanicum Poir., Schinus patagonicus (Phil.) I. M. Johnst., Myoschilos oblongum Ruiz et Pav., Alstromeria aurea Graham, Osmorhiza chilensis H., Vicia nigricans H. et A. and Mutisia decurrens Cav. This valley has had a high frequency of fire occurrence since the late $19^{\text {th }}$ century. In January 1996, an intense fire affected 400 ha of the $N$. pumilio forest, 680 ha of shrublands and pine plantations and 200 ha of grasslands (Kitzberger et al. 2005). Post-fire conditions are forests without living trees and understorey with very scarce vegetation.

Field assay. A field assay was conducted in order to evaluate: (i) post-fire soil fertility and (ii) the effect of biosolids compost application on soil characteristics and vegetation recovery. In both evaluations, we considered two types of 
microsites (LS = microsites with litter accumulation and $\mathrm{S}=$ microsites without litter accumulation) within a patch of approximately three hectares of $N$. pumilio forest burnt in 1996. Soil surface is dominated by bare mineral soil (S) without litter accumulation and patches of soils with litter accumulation (LS) close to the dead tree trunks (1 m from their base). Litter (L) was an accumulation horizon of 10-15 cm depth made up of leaves, branches and twigs, mainly of $N$. pumilio.

In early spring (September 2002), five composite soil samples (0 to $15 \mathrm{~cm}$ depth) were randomly collected from each microsite (litter soil and mineral soil) to evaluate initial soils properties. Similar analyses were performed for litter (from the study site) and biosolids compost to compare physical, chemical and physical-chemical characteristics in five samples of each type of material.

In October 2002, we randomly established 30 plots of $1 \times 1 \mathrm{~m}$ in each microsite (a total of 60 plots) throughout the study site ( $3 \mathrm{ha}$ ). Plots were spaced at least $3 \mathrm{~m}$ away from each other. A single biosolids compost rate of $2 \mathrm{~kg} \mathrm{~m}^{-2}$ (dry basis) was applied in November 2002 (early spring) in one third of the plots ( 10 plots of S soils and 10 plots of LS soils). To minimize losses due to rain and wind, a manual tillage practice was performed in the top soil $(5 \mathrm{~cm})$ of the plots in which compost was applied. Therefore, tillage was considered also as an independent treatment in order to discriminate the effect of compost application versus tillage. Subsequently, in each microsite we randomly assigned 10 plots to one of the following treatments: i) control = C; ii) tillage $=\mathrm{T}$; iii) tillage + biosolids compost application $=$ TB. We applied a $2 \mathrm{~kg} \mathrm{~m}^{-2}$ dose (low agronomic dose), that in previous studies have shown increases the fertility rates of soils in the region. Biosolids compost was produced employing shavings and yard trimming as bulking agents in the Biosolids Composting Plant of Bariloche city.

The effect of biosolids compost application on soil fertility and vegetation recovery was evaluated by assessing soils and vegetation properties. In April 2003 (autumn), after the first plant growth season, soil samples (0-15 $\mathrm{cm}$ depth) from five plots of each type of microsite and treatment were collected for physical, chemical and physical-chemical analyses. After the second growth season (April 2004), three plots of each treatment were selected and sampled to assess microbial nitrogen flush (MNF) and bulk density. Soil moisture (five replicates per microsite, treatment and date) was measured before (September 2002) and after biosolids compost application (December 2002, January to April 2003, and April 2004). Samples were passed through a $2 \mathrm{~mm}$ sieve and moisture was determined by gravimetric method at $70{ }^{\circ} \mathrm{C}$.

Total seedling density (seedlings emerged from seeds, with cotyledons per species) and vegetation cover (percent cover of all vascular plant species of the sub-plot, quadrates method; Pound and Clements 1898) were recorded at the beginning and end of the first growing season (December 2002, and April 2003, respectively) and at the end of the second growth season (April 2004) in ten sub-plots of $0.64 \mathrm{~m}^{2}$ for each treatment. Seedling density, total plant cover, species richness, richness of exotic species, diversity (Shannon-Weiner index), relative importance of exotic species (IEI: (\% of exotic species cover $/ \%$ total cover) $\mathrm{x}$ 100 ) and Czekanowski's similarity (ISC) indexes were estimated from vegetation data.

Additionally, we registered the presence of species (with and without fruits) in a border zone (an unburnt strip of $40 \mathrm{~m}$ surrounding the study area) and presented the results of a previous study of size and composition of seed bank microsites (Varela et al. 2006). Botanical nomenclature was assigned following Ezcurra and Brion (2005). Seedling determination was performed according to Puntieri and Chiapella ${ }^{1}$.

Laboratory analyses of soils, litter and compost samples. The following analyses were performed on air-dried soil samples ground to pass through a $2 \mathrm{~mm}$ sieve: $\mathrm{pH}(1: 2.5)$ and electrical conductivity (EC) (1:5) in soil: water extracts; extractable phosphorus (Olsen P) in $0.5 \mathrm{M} \mathrm{NaH}-$ $\mathrm{CO}_{3}$ by the molibdate ascorbic acid method; exchangeable cations extracted in $1 \mathrm{~N} \mathrm{NH}_{4} \mathrm{O}$ and determined by flame emission spectrometry (in the case of potassium) and atomic absorption spectrometry (in the cases of calcium and magnesium; Analist 100, Perkin Elmer Waltham). Total nitrogen by semi-micro Kjeldahl technique (Auto Kjeldahl Unit K-370, Büchi) and organic carbon by Walkley Black wet digestion, were analysed in samples passed through a $0.5 \mathrm{~mm}$ sieve.

Litter analyses were conducted on samples dried at $60{ }^{\circ} \mathrm{C}$ and ground to pass through a $1 \mathrm{~mm}$ sieve while biosolids compost air-dried samples were ground to pass through a $0.5 \mathrm{~cm}$-mesh. The following variables were determined: $\mathrm{pH}$ and electrical conductivity in 1:10 aqueous extracts and extractable phosphorus as mentioned above. Total phosphorus, calcium, magnesium and potassium were analysed by dry digestion at $550{ }^{\circ} \mathrm{C}$ and $\mathrm{HCl}$ extraction, followed by colorimetric (phosphorus), flame emission spectrometric (potassium) and atomic absorption spectrometry determinations (calcium and magnesium; Analist 100, Perkin Elmer Waltham). Total carbon was determined by dry digestion at $550{ }^{\circ} \mathrm{C}$ and total nitrogen by semi-micro Kjeldahl (Auto Kjeldahl Unit K-370, Büchi). Composts and litter methodologies corresponded to those described by Laos et al. (2002) and Diehl et al. (2003), respectively.

The evaluation of microbial nitrogen flushes as an index of available nitrogen is a fundamental tool due to that reflects the immediate availability of this nutrient and the potential availability in the short term due to the mineralization of microbial nitrogen tissue. Microbial nitrogen flush was assessed in moist field samples, using a modification of the chloroform fumigation-incubation technique

${ }^{1}$ Puntieri J, J Chiapella. Plántulas de la zona sur de Argentina y Chile. Fantástico Sur Editorial, Punta Arenas, Chile. (in press). 
(Vitousek and Matson, 1985). After incubation (10 days at $25^{\circ} \mathrm{C}$ ), samples were extracted with $2 \mathrm{M} \mathrm{KCl}$ at a $1: 5$ ratio sample: solution and analysed for $\mathrm{N}-\mathrm{NH}_{4}^{+}$by the indophenol-blue method (Keeney and Nelson 1982), employing the "Uremia" kit from Wiener laboratory. Microbial nitrogen flush was calculated as the difference between fumigated and non-fumigated samples.

Bulk density was determined in soil samples extracted with a known volume cylinder, passed through a $2 \mathrm{~mm}$ sieve (without stones) and dried at $105{ }^{\circ} \mathrm{C}$.

Statistical analyses. Data of soil fertility variables (before compost application), litter and compost were compared by one-way analysis of variance (ANOVA). Two-way ANOVAs combined with Tukey test were used to study microsite conditions (litter/soil and mineral soil) and treatment effects on soil fertility and field vegetation (total richness, exotic richness, total cover, density and diversity) parameters after biosolids compost application (start and end of first growth season and end of the second growth season). In both cases, we used the microsite type and treatments (control, tillage and tillage + biosolids) as factors. Data transformations were carried out when necessary to ensure the validity of the assumptions of normality, linearity, and homoscedasticity. In each case in which transformation was not possible, a non-parametrical test of Mann-Whitney was applied. The significance level in all cases was $P<0.05$. The software STATISTICA 7.0 Stat Soft Inc. (2004) was used for all the analyses.

\section{RESULTS}

\section{Soil fertility}

- Initial soil properties: soils with litter accumulation (LS) had higher $\mathrm{pH}$ and extractable phosphorus (Olsen P) than those found in soils without litter accumulation (S; table 1), and no differences in concentrations of nitrogen, potassium, magnesium and calcium (table 1). Differences found in $\mathrm{pH}$ values showed no significance in biological terms (differences lower than one unit did not differentially influence biological processes), but extractable phosphorus values in soils with litter accumulation triplicated those in mineral soil. Soils with litter accumulation had $16 \%, 30 \%, 15 \%$ and $66 \%$ more of nitrogen, potassium, magnesium and calcium respectively, than did soils without litter accumulation. Average moisture values registered in soils with litter accumulation tended to be higher than those registered in mineral soil ( $36.9 \pm 6.5$ vs. $27.9 \pm$ $6.9 \%$ soil gravimetric moisture respectively; $P=0.067$; data not shown). Comparatively, biosolids compost represented a material with higher values of nitrogen, magnesium, extractable phosphorus and total phosphorus, and lower levels of organic carbon and carbon: nitrogen ratio than those values found in litter $(P<0.05$; table 1$)$.

- Effects of biosolids compost application on soils properties: the biosolids compost application (TB) produced increases in organic carbon, potassium and in extractable phosphorus in both microsites compared to tillage ( $\mathrm{T}$ ) and control $(\mathrm{C})$ treatments for the first two variables and respect to control treatment for the last variable (table 2). Interaction between microsite type and treatment was not found in any case $\left(P_{\text {int. }}>0.05\right.$, table 2$)$. Tillage and tillage + biosolids compost application showed a slow, non-significant trend to reduce bulk density values (soil-control $=0.59 \mathrm{Mg} \mathrm{m}^{-3}$, soil-tillage $=0.53 \mathrm{Mg} \mathrm{m}^{-3}$, soil-tillage and biosolids compost application $=0.52 \mathrm{Mg} \mathrm{m}^{-3}, P=0.456$ and soils with litter accumulation-control $=0.58 \mathrm{Mg} \mathrm{m}^{-3}$, soils with litter accumulation-tillage $=0.55 \mathrm{Mg} \mathrm{m}^{-3}$, soils with litter accumulation - biosolids compost $=0.52 \mathrm{Mg}$ $\mathrm{m}^{-3}, P=0.571$; data not shown).

Microbial nitrogen flush (figure 1) varied from 3.7 to $7.5 \mathrm{~N}^{-\mathrm{NH}_{4}} \mu \mathrm{g} \mathrm{g}^{-1}$ soil in control condition and had higher values under biosolids compost application treatment $\left(P_{\text {treat. }}=0.000\right.$; figure 1) compared to control and tillage treatments in both microsites. Soil without litter accumulation showed similar values of microbial nitrogen flush

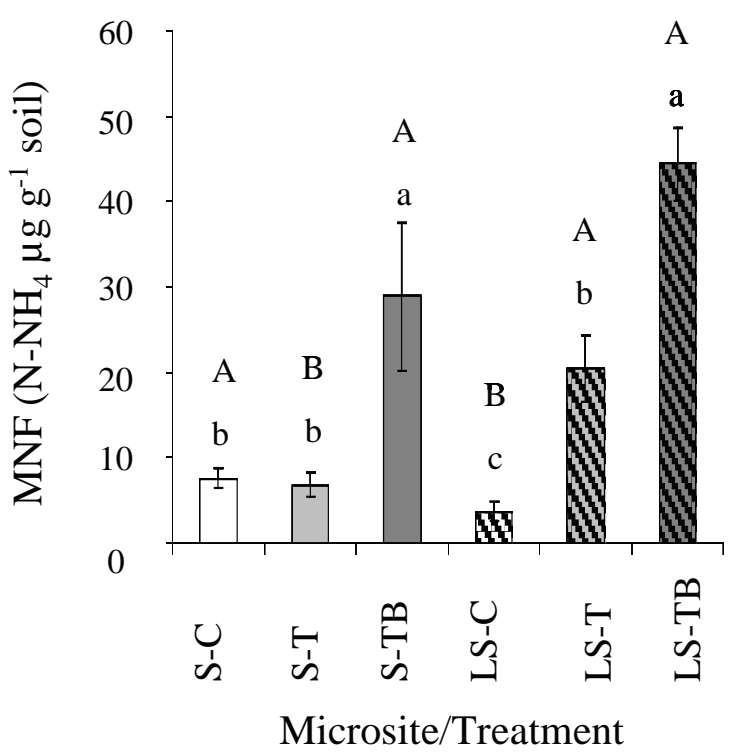

Figure 1. Microbial nitrogen flush $(\mathrm{MNF} ; \pm \mathrm{SD})$ for the different treatments ( $\mathrm{n}=3$ per treatment). Different lowercase letters among bars indicate significant differences among treatments per microsite. Capital letters show differences between microsites per treatment. References $S=$ soil without litter accumulation (dotted bars); LS: soil with litter accumulation (striped bars); -C= control; $-\mathrm{T}=$ tillage; $-\mathrm{TB}=$ tillage and biosolids compost application.

Flujo de nitrógeno microbiano (MNF; $\pm \mathrm{SD}$ ) para los diferentes tratamientos ( $\mathrm{n}=3$ por tratamiento). Letras minúsculas diferentes entre barras del gráfico indican diferencias estadísticas significativas entre tratamientos por micrositio. Letras mayúsculas diferentes muestran diferencias estadísticas significativas entre micrositios por tratamiento. Referencias $\mathrm{S}$ = suelo sin acumulación de hojarasca (barras punteadas); LS: suelo con acumulación de hojarasca (barras rayadas); -C = control; - $\mathrm{T}$ = labranza; $-\mathrm{TB}=$ labranza y aplicación de compost de biosólidos. 


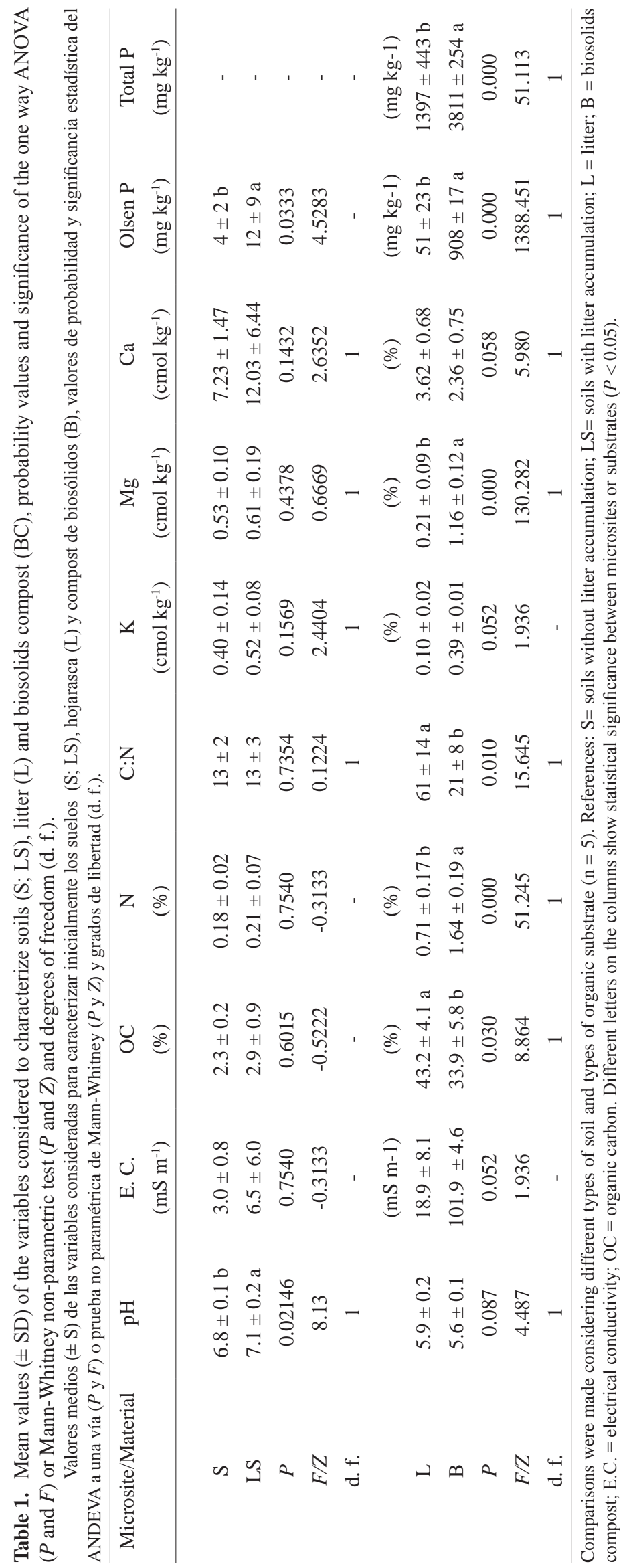


BOSQUE 32(3): 267-278, 2011

Use of biosolids compost on burned forest

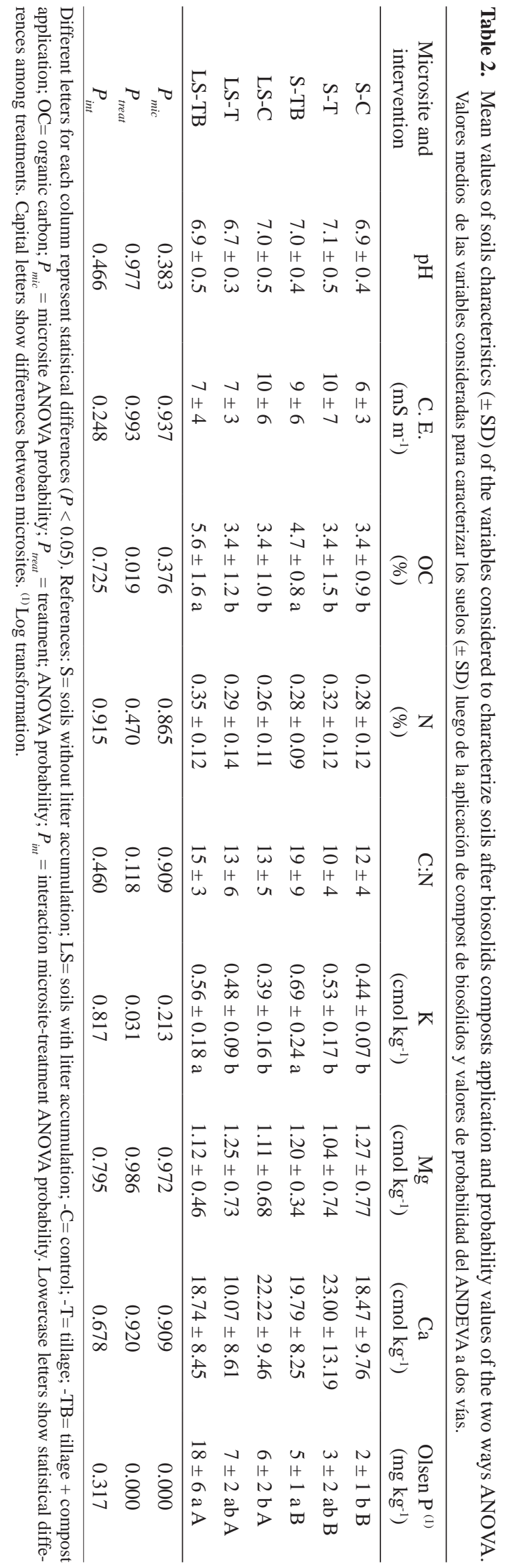


content in control and tillage plots (figure 1). There was an effect of microsite type $\left(P_{\text {mic. }}=0.029\right)$ and micrositetreatment interaction $\left(P_{i n t .}=0.000\right)$. Moisture values did not differ between mineral soils and litter soils for all sampling dates. The maximum values registered corresponded to December (28 and $33 \%$ ) and the minimum values to March (4\%; data not shown).

Effects of biosolids compost application on vegetation. Total understory of burnt $N$. pumilio forest (control microsites = soil-control + soils with litter accumulation-control; Appendix 1) was made up of 17 species, with predominance of herbaceous species (59 \%) and a high percentage of exotic species (47\%). Both microsites were very similar in native and exotic species composition (ISC $\mathrm{LS}_{\text {LS; S-C }}$ $=0.64-0.69$, respectively). During the study period, total vegetation cover (TC) varied from 14 to $65 \%$ and seedling density was higher (double) in soil-control than it was in soils with litter accumulation-control microsites (table 3). Herbaceous and grass species, in decreasing order of dominance, were Epilobium paniculatum, Carduus nutans, Bromus sp., Hordeum comosum, Vicia nigricans and Cirsium vulgare (figure 2).

Of the species identified in the border zone, 46 and $37 \%$ were also registered in soil-control and soils with litter accumulation-control, respectively (Appendix 1). Of the species registered in a previous seed bank study, $44 \%$ and $38 \%$ were also found in soil-control and soils with litter accumulation-control microsites, respectively (Appendix 1). Similarity of vegetation (ISC) increased over time (ISC less than 0.46 in the first growth season and greater than 0.60 in the second) independently of the microsite considered.

Biosolids compost application promoted the emergence of native Stipa sp. in mineral soil, the exotic Leucanthemum vulgare and Matricaria matricarioides in soils with litter accumulation and Chenopodium album in both microsites (Appendix 1).

Five native species were absent in plots with compost application or tillage treatment: Loasa bergii and N. pumilio in soils with litter accumulation and Acaena pinnatifida and Ribes magellanicum in mineral soil microsites. Solidago chilensis was absent in mineral soil microsite and in soils with litter accumulation with biosolids compost application. The exotic Brassica sp. was present only in soils without litter accumulation microsite and control treatment in mineral soil microsite (Appendix 1). Presence of C. album, L. vulgare and M. matricarioides was associated with biosolids compost application only for the first growing season, whereas Maytenus chubutensis, Phacelia secunda, Stipa sp., Holcus lanatus and Taraxacum officinale were present only in tillage practices, independently of compost application.

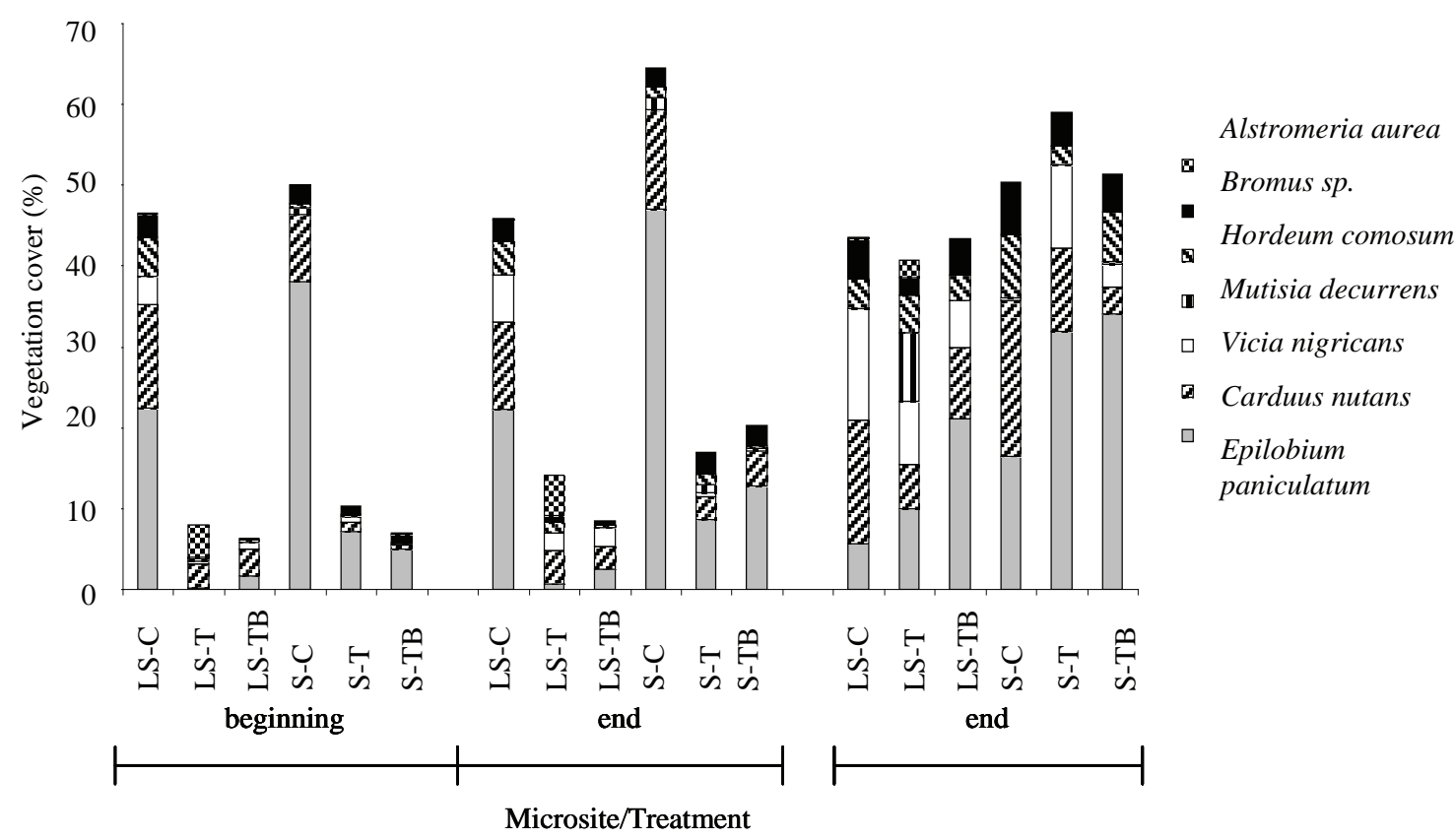

Figure 2. Mean values of vegetation cover per plot (microsite/treatment) of the seven dominant species in the first growing season (beginning and end) and second growing season (end). References $\mathrm{S}=$ soil without litter accumulation; LS= soil with litter accumulation; $-\mathrm{C}=$ control; $-\mathrm{T}=$ tillage; $-\mathrm{TB}=$ tillage and biosolids compost application.

Valores medios de cobertura de la vegetación por parcela (micrositio/tratamiento) de las siete especies principales en la primera estación de crecimiento (principios y fines) y la segunda estación de crecimiento (fin). Referencias: $\mathrm{S}=$ suelo sin acumulación de hojarasca; LS = suelo con acumulación de hojarasca; -C = control; -T = labranza; -TB = labranza y aplicación de compost de biosólidos. 
Independently of the microsite type, time of register (beginning or end) and growth season considered, total richness had similar values in tillage and tillage and biosolids compost application treatment compared to control plots. Exotic richness presented a reduction only in plots of litter soils during the first growth season (beginning and end). Early in the first growing season, tillage and tillage and biosolids compost application, independently of the microsite considered, had lower values of seedling density and total cover compared to control plots (only 12 to $31 \%$ of seedling density and 14 to $22 \%$ of total cover vegetation; $P<0.05$; table 3). Seedling density was more affected by tillage treatment than by tillage + biosolids compost application in soils with litter accumulation microsite. Diversity of species tends to be higher in litter soils microsite compared to mineral soil microsite $\left(P_{\text {mic. }}=0.025\right.$ at the start and $P_{\text {mic. }}=0.013$ at the end of the first growth season; table 3). In all cases, IEI values were greater than $70 \%$.

During the second growth season, similar values of total richness, exotic richness, density of seedlings and total cover were registered in all treatments, within microsites and between microsites. The density of seedlings tended to increase in tillage and compost application plots (20 to $31 \%$ in soils without litter accumulation and 49 to $137 \%$ in soils with litter accumulation). The importance of exotic species (IEI) in most treatments shows a trend to decrease

Table 3. Mean values of field vegetation parameters at the beginning and end of the first growth season and end of the second growth season per microsite and treatment.

Valores medios de los parámetros de vegetación al comienzo y fin de la primera estación de crecimiento y fin de la segunda estación de crecimiento por micrositio y tratamiento.

\begin{tabular}{|c|c|c|c|c|c|c|}
\hline Microsite/ Treatment & $\mathrm{TR}\left(\mathrm{N}^{\circ}\right)$ & $\operatorname{ER}\left(\mathrm{N}^{\circ}\right)$ & $\mathrm{D}^{(1)}\left(\mathrm{N}^{\circ} \mathrm{m}^{-2}\right)$ & $\mathrm{TC}^{(1)}(\%)$ & IEI (\%) & $\mathrm{H}^{\prime}$ \\
\hline \multicolumn{7}{|c|}{ Beginning of the first growth season } \\
\hline $\mathrm{S}-\mathrm{C}$ & $3.50 \pm 1.27$ & $3.10 \pm 1.20 \mathrm{a}$ & $182 \pm 64$ a $A$ & $51.0 \pm 19.4 \mathrm{a}$ & $97.0 \pm 5.8$ & $0.52 \pm 0.29 \mathrm{~B}$ \\
\hline $\mathrm{S}-\mathrm{T}$ & $2.90 \pm 0.88$ & $2.30 \pm 0.67 b$ & $32 \pm 27$ b A & $10.6 \pm 13.6 b$ & $82.9 \pm 20.4$ & $0.72 \pm 0.35 \mathrm{~B}$ \\
\hline S-TB & $3.60 \pm 1.58$ & $3.10 \pm 0.99 a b$ & $57 \pm 70 \mathrm{~b} \mathrm{~A}$ & $9.0 \pm 8.2 b$ & $94.6 \pm 8.2$ & $0.71 \pm 0.44 \mathrm{~B}$ \\
\hline LS-C & $4.40 \pm 1.71$ & $3.80 \pm 1.32 \mathrm{a}$ & $115 \pm 75$ a $\mathrm{B}$ & $48.7 \pm 29.9 \mathrm{a}$ & $91.3 \pm 20.8$ & $0.83 \pm 0.29 \mathrm{~A}$ \\
\hline LS-T & $3.20 \pm 2.10$ & $2.60 \pm 1.51 \mathrm{~b}$ & $14 \pm 13 \mathrm{~b} \mathrm{~B}$ & $8.9 \pm 19.3 \mathrm{~b}$ & $71.5 \pm 34.9$ & $0.92 \pm 0.35 \mathrm{~A}$ \\
\hline LS-TB & $3.60 \pm 1.43$ & $3.20 \pm 1.40 \mathrm{ab}$ & $35 \pm 53$ b B & $7.3 \pm 11.2 \mathrm{~b}$ & $87.4 \pm 27.3$ & $0.86 \pm 0.44 \mathrm{~A}$ \\
\hline$P_{\text {mic }}$ & 0.319 & 0.247 & 0.005 & 0.071 & - & 0.025 \\
\hline$P_{\text {treat }}$ & 0.186 & 0.034 & 0.000 & 0.000 & - & 0.440 \\
\hline$P_{i n t}$ & 0.644 & 0.729 & 0.636 & 0.651 & - & 0.799 \\
\hline \multicolumn{7}{|c|}{ End of the first growth season } \\
\hline $\mathrm{S}-\mathrm{C}$ & $3.40 \pm 1.07$ & $3.30 \pm 1.25$ a & $198 \pm 105$ a $A$ & $65.3 \pm 28.8 \mathrm{a}$ & $96.7 \pm 10.5$ & $0.43 \pm 0.25 \mathrm{~B}$ \\
\hline $\mathrm{S}-\mathrm{T}$ & $3.00 \pm 1.15$ & $2.40 \pm 0.84 b$ & $36 \pm 40 \mathrm{~b} \mathrm{~A}$ & $17.2 \pm 11.7 \mathrm{~b}$ & $88.6 \pm 19.8$ & $0.69 \pm 0.43 \mathrm{~B}$ \\
\hline S-TB & $3.50 \pm 1.27$ & $3.20 \pm 0.92 \mathrm{ab}$ & $46 \pm 36 \mathrm{~b} \mathrm{~A}$ & $23.5 \pm 19.9 \mathrm{~b}$ & $97.5 \pm 5.6$ & $0.71 \pm 0.39 \mathrm{~B}$ \\
\hline LS-C & $4.70 \pm 1.83$ & $3.90 \pm 0.88 \mathrm{a}$ & $98 \pm 94$ a B & $47.2 \pm 31.0 \mathrm{a}$ & $88.1 \pm 21.2$ & $0.84 \pm 0.37 \mathrm{~A}$ \\
\hline LS-T & $3.60 \pm 1.65$ & $2.90 \pm 1.29 \mathrm{~b}$ & $18 \pm 14 \mathrm{~b} \mathrm{~B}$ & $17.2 \pm 24.7 \mathrm{~b}$ & $68.2 \pm 35.6$ & $0.98 \pm 0.51 \mathrm{~A}$ \\
\hline LS-TB & $3.50 \pm 1.51$ & $3.20 \pm 1.32 \mathrm{ab}$ & $24 \pm 19 b \mathrm{~B}$ & $11.3 \pm 9.9 \mathrm{~b}$ & $79.0 \pm 38.6$ & $0.81 \pm 0.41 \mathrm{~A}$ \\
\hline$P_{\text {mic }}$ & 0.094 & 0.203 & 0.003 & 0.084 & - & 0.013 \\
\hline$P_{\text {treat }}$ & 0.242 & 0.030 & 0.000 & 0.000 & - & 0.288 \\
\hline$P_{i n t}$ & 0.367 & 0.655 & 0.982 & 0.442 & - & 0.465 \\
\hline \multicolumn{7}{|c|}{ End of the second growth season } \\
\hline $\mathrm{S}-\mathrm{C}$ & $3.86 \pm 1.35$ & $3.57 \pm 1.40$ & $97 \pm 75$ & $53.4 \pm 19.8$ & $99.5 \pm 1.2$ & $0.69 \pm 0.44 \mathrm{~B}$ \\
\hline $\mathrm{S}-\mathrm{T}$ & $4.00 \pm 1.63$ & $3.43 \pm 1.40$ & $117 \pm 76$ & $59.9 \pm 22.0$ & $84.0 \pm 21.1$ & $0.68 \pm 0.44 \mathrm{~B}$ \\
\hline S-TB & $3.57 \pm 1.27$ & $3.29 \pm 1.25$ & $127 \pm 68$ & $52.7 \pm 20.1$ & $91.0 \pm 18.8$ & $0.55 \pm 0.55 \mathrm{~B}$ \\
\hline LS-C & $4.86 \pm 1.46$ & $3.86 \pm 1.46$ & $49 \pm 25$ & $46.5 \pm 30.9$ & $82.9 \pm 28.5$ & $1.20 \pm 0.40 \mathrm{~A}$ \\
\hline LS-T & $4.71 \pm 1.11$ & $3.29 \pm 1.11$ & $73 \pm 43$ & $43.9 \pm 24.5$ & $65.8 \pm 26.4$ & $1.01 \pm 0.58 \mathrm{~A}$ \\
\hline LS-TB & $4.43 \pm 1.72$ & $3.86 \pm 1.21$ & $116 \pm 74$ & $46.2 \pm 21.0$ & $90.7 \pm 18.1$ & $0.67 \pm 0.48 \mathrm{~A}$ \\
\hline$P_{m i c}$ & 0.0615 & 0.5603 & 0.0862 & 0.1844 & - & $0.0389 *$ \\
\hline$P_{\text {treat }}$ & 0.7519 & 0.7705 & 0.1469 & 0.9584 & - & 0.1930 \\
\hline$P_{i n t}$ & 0.9661 & 0.7705 & 0.6939 & 0.8336 & - & 0.5739 \\
\hline
\end{tabular}

References: Total richness (TR), richness of exotic species (ER), density of seedlings (D), total cover (TC), relative importance of exotic species index (IEI) and diversity $\left(\mathrm{H}^{\prime}\right)$ per microsite and treatment and probabilities of two way ANOVA at the beginning and end of the first growing season and at the end of the second: $P_{\text {mic }}=$ microsite; $P_{\text {treat }}=$ treatment and $P_{\text {int }}=$ interaction between microsite and treatment $(P>0.05) .{ }^{(1)}=$ Transformation log $(\mathrm{x}+0.5)$. $\mathrm{S}=$ soil without litter accumulation; $\mathrm{LS}=$ soil with litter accumulation; $-\mathrm{C}=$ control; $-\mathrm{T}=$ tillage; $-\mathrm{TB}=$ tillage and biosolids compost application . Capital letters show differences between microsites. Lowercase letters shows differences among treatments per microsite. 
in this growth season. Diversity was higher in soils with litter accumulation-control than in mineral soil-tillage and biosolids compost application (table 3).

\section{DISCUSSION AND CONCLUSIONS}

Post fire soil characteristics and differences between microsites. Comparing previous studies on soil fertility variables in post-fire Challhuaco Valley (Satti et al. 2003, Alauzis et al. 2004, Kitzberger et al. 2005) with the results obtained in the present study, a lack of recovery in soil fertility eight years after fire (carbon, nitrogen, microbial nitrogen flush, $\mathrm{pH}$, potassium and extractable phosphorus, for example) can be observed. This indicates the high disturbance intensity and the low post-disturbance resilience of these forests. Fire induced significant decreases in soil carbon, total nitrogen and an even more marked seven-fold significant difference in nitrogen retained in microbial biomass between burned and unburned soil samples (Alauzis et al. 2004). This reduced microbial biomass coupled with relatively high inorganic nitrogen production implies a severe risk for nitrogen losses (Kitzberger et al. 2005). Even considering the high buffer capacity of volcanic soils, the lack of recovery highlights the need to develop techniques for soil fertility and vegetation regeneration assistance in these systems. Differences found between microsites (table 1) showed that litter probably had an effect on soil fertility. As we hypothesised, this effect may be attributed directly to organic matter contribution and, indirectly, to the physical protection from rain or wind erosion provided by litter. With reference to microsite conditions, there is seasonal variability in soils nutrient contents, independent of the microsite considered (control treatment; tables 2 and 3), in agreement with Alauzis et al. (2004). In many cases, litter quality exerts important feedback on nitrogen dynamics, regulating rates of decomposition, nitrogen availability, net primary production and responses to disturbance (Satti et al. 2003).

Biosolids compost application as a restoration tool: Is compost useful when applied at low doses? In this particular study case, considering that the study was conducted within a protected area (National Park), the possibilities for developing soil fertility or vegetation restoration techniques were limited (e.g. rates of amendment applied to the soil). Many of the organic amendments application techniques (and particularly compost amendments) can promote not only the expression of native species but also exotic species. Considering this point, our study applied a low dose of biosolids compost in order to evaluate whether it was adequate. As far as we know, to date there are no studies that specifically consider the effects of application dose on soil fertility and vegetation in protected areas (e.g. National Parks) and this is the first study in this topic in Patagonian Andean forests.
As mentioned above, biosolids compost application increased carbon, potassium and extractable phosphorus in both microsites, additionally showing a higher trend to increase total nitrogen almost in soils with litter accumulation. These results are contrary to those found by Cuevas et al. (2000) in soils with other types of disturbance (i.e.: water erosion), and for other kind of composts (solids urban residuals). These authors did not find significant increases in total carbon and nitrogen concentrations in spite of the high rates employed. Other authors (e.g. Larchevêque et al. 2008) found significant increases even when using lower application rates. Therefore, either the characteristics of the disturbance or the characteristics of the amendment applied drive the magnitude of the change and the success of the restoration strategy. Thus, there is an optimal relationship between the characteristics of the organic amendment to be applied in a certain site, type and intensity of the previous disturbance. As an example of this, Larchevêque et al. (2008) found that the enhancement of soil fertility due to compost appeared less durable at an application dose of $20 \mathrm{Mg} \mathrm{ha}^{-1}$ than at $40 \mathrm{Mg} \mathrm{ha}^{-1}$. Additionally, these authors found significant effects of the amendment over soil fertility parameters but not for vegetation parameters. In this sense, certain types of amendments are useful for improving certain aspects (e.g. soil fertility), but not for others (e.g. recovery of vegetation), at least in the short term.

In the present study, biosolids compost application tended to increase total soil nitrogen, whereas microbial nitrogen flush (proper soil nitrogen) was four to twelve times higher in plots with biosolids compost application compared to control plots. Nitrogen is one of the most limiting nutrients for plant growth and is rapidly absorbed when supplied to seedlings. This trend of increase was particularly important in a system which, eight years after the fire, did not show any nitrogen recovery (Diehl et al. 2003, this study). The marked increase in the microbial population could be the result either of the direct addition of compost microorganisms or of the addition of organic matter.

Extractable phosphorus (Olsen P) generally increased with compost application, as reported by several authors (e.g. Martinez et al. 2003, Larchevêque et al. 2008). In this study, the increase of extractable phosphorus in tillage and biosolids compost application treatment was apparently not associated with an increase in soil organic matter, with extractable phosphorus values being close to those registered in an unburnt $N$. pumilio forests (Diehl et al. 2003). This effect may be related to phosphorus and organic matter added from litter block phosphorus-retention sites in these volcanic soils, allowing a higher availability of phosphorus added by biosolids compost. These differences and tendencies may indicate that if higher rates of amendment were applied, a more significant improvement in soil fertility could be expected. In ecosystem restoration with compost amendments, long-term improvement of soil fertility is a major objective because it may ensure successful plant 
establishment and growth (Larchevêque et al. 2008).

Regarding vegetation, seven to eight years after fire, herbaceous exotic species had high dominance in terms of cover, which may protect the soil against erosion and contribute to soil organic matter and seed retention by physical mechanisms. These species, which are mainly heliophilous and anemophilous (pioneer species), do not seem to compete strongly subsequently with the native species. However, they leave broad areas of uncovered soil surface where native species may become established, and form a low, sparse leaf layer allowing access to light to new plants.

In the present study, the possibility of invasion and the attributes of the exotic species (e.g. tolerance to climatically adverse conditions, nutritional requirements) seem to be major factors in the process of regeneration. Total understorey of $N$. pumilio burnt forest was made up mainly of herbaceous species, with a high percentage of exotic species and without differences in native and exotic composition between microsites. It should be noted that none of the exotic species recorded was introduced intentionally by man in the study area. Some of the native species of these forests have a high capacity of resprouting from buds located close to the soil surface (Brion et al. 1988) when they are not eliminated by fire. Intense fire limits resprouting as a mechanism for reestablishment in comparison to high production and dispersion of seeds originated in the boundary zone of the fire. Additionally, it is worth noting that the regenerative capacity of the dominant species in pre-disturbance conditions ( $N$. pumilio) is greatly threatened by direct incineration of the seedling bank and by the lack of resprouting ability.

After fire, native $N$. pumilio forests regeneration is very low and, as we show in the present study, the addition of organic amendments enhances post-fire soil fertility conditions. Although microsites tended to increase their seedling density after biosolids compost applications, at least in the short term (two growth seasons), this did not produce a high recovery of the plant community. We can also see that some species were closely associated with some fertility value or microsite (e.g. L. vulgare and M. matricarioides on soils with litter accumulation - tillage and biosolids compost application, closely related to nitrogen and extractable phosphorus). This point must be taken into account in future studies, regarding particular objectives, if some kinds of species are to be avoided (e.g. nitrofilous species), or restoration techniques must be focused on those species or microsites of interest. Together with higher application doses, this practice may probably enhance the number of native and exotic species over longer times, and favour soil protection, increasing nutrient cycling and the frequency of appropriate microsite conditions that promote subsequent seedling recruitment (Varela et al. 2006). However, this point must be evaluated for each particular case.

Exotic species are good competitors immediately after disturbance, but not in the long-term. Management prac- tices that allow the development of exotic species that do not alter the establishment of native species ought to be considered as efficient tools in the recovery of degraded environments.

The addition of tillage in soils near to trunks (soils with litter accumulation), registered on all dates caused a slight decrease of exotic species. This may be due to the contribution of native species that appeared in zones without litter accumulation after tillage. In order to reduce the effect of tillage (table 3 ) on vegetation germination and expression, other techniques of amendment application that do not include the tillage practices should be investigated in future studies.

The addition of seeds from compost depends markedly on the season of the year, the fruiting cycles of the species and the rate of seed production near the mature compost collection sites. It is important to evaluate this in future studies involving the application of organic amendments that may contain seeds, as often occurs with biosolids compost or municipal sewage sludge.

These results confirm that organic amendment application may be used as an initial restoration strategy at microsite level in burnt $N$. pumilio forests related principally to a beneficial effect on soil fertility. The creation of fertility islands can be a valid restoration strategy, but mechanisms to increase the reinstallation of native vegetation should be also applied.

\section{ACKNOLEDGMENTS}

We wish to thank PNNH for its permission to install field assays in the Challhuaco zone, Soil Group staff of UNComahue for their help with field assays and laboratory analyses and J. Puntieri, M. Weigandt, M. Gomez Berisso, J. Cortina Segarra and two anonymous reviewers for their comments on early drafts of this paper. This study was partially supported by a grant from Universidad Nacional del Comahue.

\section{REFERENCES}

Alauzis MV, MJ Mazzarino, E Raffaele, L Roselli. 2004. Wildfires in NW Patagonia: long-term effects on a Nothofagus forest soil. Forest Ecology and Management 192: 131-142.

Barros VR, VH Cordon, CL Moyano, RJ Méndez, JC Forquea, O Pizzio. 1983. Cartas de precipitación de la zona oeste de las provincias de Río Negro y Neuquén. Buenos Aires, Argentina. CONICET. 28 p.

Brion C, D Grigera, J Puntieri, E Rapoport. 1987. Observaciones sobre el poblamiento de plantas exóticas en bosques de Nothofagus. Abstracts $1^{\circ}$ Simposio sobre Nothofagus. Neuquén, Argentina. 49 p.

Cuevas G, S García, R Calvo, I Walter. 2000. Evaluación del desarrollo de la vegetación autóctona de un suelo degradado tratado con residuos sólidos urbanos. Ecología 14: 89-102.

de Torres Curth M, L Ghermandi, G Pfister. 2002. Relationship between burned area and meteorological variables in Nor- 
thwestern Patagonia. In Forest Fire Research \& Wildland Fire Safety. IV International Conference on Forest Fire Research, Luso, Coimbra, Portugal. Millpress Science Publishers. $12 \mathrm{p}$.

Diehl P, MJ Mazzarino, F Funes, S Fontenla, M Gobbi, J Ferrari. 2003. Nutrient conservation strategies in native Andean-Patagonian forests. Journal of Vegetation Science 14: 63-70.

Ezcurra C, C Brion. 2005. Plantas del Nahuel Huapi. Catálogo de la flora vascular del Parque Nacional Nahuel Huapi, Argentina. Universidad Nacional del Comahue. Red Latinoamericana de Botánica. 70 p.

Heinemann K, T Kitzberger. 2006. Effects of position, understorey vegetation and coarse woody debris on tree regeneration in two environmentally contrasting forests of northwestern Patagonia: a manipulative approach. Journal of Biogeography 33(8): 1357-1367.

Keeney DR, DW Nelson. 1982. Nitrogen-Inorganic forms. In Page AL, RH Miller, DR Keeney eds. Methods of Soil Analysis. Part. 2. Serie Agronomy, ASA-SSSA. Madison, Wisconsin, USA. p. 643-698.

Kitzberger T, E Raffaele, K Heinemann, MJ Mazzarino. 2005. Effects of fire severity in north subalpine forests. Journal of Vegetation Science 16: 5-12.

Laos F, MJ Mazzarino, I Walter, L Roselli, P Satti, S Moyano. 2002. Composting of fish offal and biosolids in NW Patagonia. Bioresource Technology 82: 179-186.

Larchevêque M, N Montès, V Baldy, C Ballini. 2008. Can compost improve Quercus pubescens Willd establishment in a Mediterranean post-fire shrubland? Bioresource Technolo- gy 99: 3754-3764.

Martinez F, G Cuevas, R Calvo, I Walter. 2003. Biowaste effects on soil and native plants en semiarid ecosystems. Journal of Environmental Quality 32: 472-479.

Mazzarino MJ, F Laos. 2000. Composting biosolids in Patagonia. BioCycle 41(4): 83-85.

Pound R, FE Clements. 1898. A method of determining the abundance of secondary species. Minnesota Bot. Studies 2: 1924.

Satti P, MJ Mazzarino, M Gobbi, F Funes, L Roselli, H Fernández. 2003. Soil N dynamics in relation to leaf litter quality and soil fertility in north-western Patagonian forests. Journal of Ecology 91: 173-181.

Schmidt H, A Lara. 1985. Potencialidad de los Bosques Nativos Chilenos. Ambiente y Desarrollo 1(2): 91-108.

Tegart G. 2004. Fire Effects on soil. Fire Effects on Rangeland. Factsheet 2 of 6 in the Fire Effects on Rangeland Factsheet Series. British Columbia. Ministry of Agriculture, Food and Fisheries.

Varela S, ME Gobbi, F Laos. 2006. Banco de semillas de un bosque quemado de Nothofagus pumilio: efecto de la aplicación de compost de biosólidos. Ecología Austral 16: 63-78.

Veblen TT, T Kitzberger, E Raffaele, M Mermoz, ME González, JS Sibold, A Holz. 2008. The historical range of variability of fires in the Andean-Patagonian Nothofagus forest region. International Journal of Wildland Fire 17: 724-741.

Vitousek PM, PA Matson. 1985. Disturbance, N-availability and N-losses: An experimental study in an intensively managed loblolly pine plantation. Ecology 66: 1360-1376.

Recibido: 03.03.11

Aceptado: 12.08.11 
Appendix 1. List of plant species per microsite/treatment (absence/presence), seed bank and border zone. The life form and sprouting capacity (Spr.) of each species are indicated.

Lista de las especies de plantas por micrositio/ tratamiento (ausencia/presencia), banco de semillas y zona borde del área de bosque quemada. Se indica la forma de vida y la capacidad de rebrote (Spr.) de cada especie. Referencias: S = suelo sin acumulación de hojarasca (barras punteadas); LS: suelo con acumulación de hojarasca (barras rayadas); -C = control; - $\mathrm{T}$ = labranza; -TB = labranza y aplicación de compost de biosólidos; $\mathrm{SH}=$ arbusto, $\mathrm{T}$ = árbol, $\mathrm{AH}$ = hierba anual, $\mathrm{BH}=$ hierba bianual, $\mathrm{PH}=$ hierba perenne, $\mathrm{UH}=$ hierba con duración del ciclo de vida no conocido, $\mathrm{G}=$ pastos, $\mathrm{V}=$ enredaderas; $*$ = fructificación registrada; ${ }^{\phi}$ Varela et al. (2006).

\begin{tabular}{|c|c|c|c|c|c|c|c|c|c|c|}
\hline \multirow[b]{2}{*}{ Species } & \multicolumn{10}{|c|}{ Treatments } \\
\hline & $\begin{array}{l}\text { Life } \\
\text { form }\end{array}$ & Spr. & $\mathrm{S}-\mathrm{C}$ & S-T & S-TB & LS-C & LS-T & LS-TB & $\begin{array}{c}\text { Seed }{ }^{(\phi)} \\
\text { bank }\end{array}$ & $\begin{array}{c}\text { Border } \\
\text { zone }\end{array}$ \\
\hline \multicolumn{11}{|l|}{ Native } \\
\hline Acaena pinnatifida* & $\mathrm{SH}$ & Yes & $\mathrm{X}$ & - & - & - & - & - & - & $\mathrm{X}$ \\
\hline Alstroemeria aurea & $\mathrm{PH}$ & - & $\mathrm{X}$ & - & $\mathrm{X}$ & $\mathrm{X}$ & $\mathrm{X}$ & $\mathrm{X}$ & - & $\mathrm{X}$ \\
\hline Anemone multifida* & $\mathrm{PH}$ & - & - & - & - & - & - & - & - & $\mathrm{X}$ \\
\hline Baccharis rhomboidalis* & $\mathrm{SH}$ & - & - & - & - & - & - & - & - & $\mathrm{X}$ \\
\hline Berberis buxifolia & $\mathrm{SH}$ & Yes & - & - & - & - & - & - & - & $\mathrm{X}$ \\
\hline Berberis serrate-dentata* & $\mathrm{SH}$ & Yes & - & - & - & - & - & - & - & $\mathrm{X}$ \\
\hline Cynanchum nummulariifolium & $\mathrm{PH}$ & - & - & - & - & - & - & - & - & $\mathrm{X}$ \\
\hline Fragaria chiloensis $*$ & $\mathrm{PH}$ & - & - & - & - & - & - & - & - & $\mathrm{X}$ \\
\hline Leucheria thermarum & $\mathrm{PH}$ & - & - & - & - & - & - & - & - & $\mathrm{X}$ \\
\hline Loasa bergii & $\mathrm{PH}$ & - & - & - & - & $\mathrm{X}$ & - & - & - & $\mathrm{X}$ \\
\hline Maytenus chubutensis* & $\mathrm{SH}$ & Yes & - & - & - & - & $\mathrm{X}$ & $\mathrm{X}$ & - & $\mathrm{X}$ \\
\hline Mutisia decurrens* & $\mathrm{V}$ & - & $\mathrm{X}$ & $\mathrm{X}$ & $\mathrm{X}$ & - & $\mathrm{X}$ & - & - & $\mathrm{X}$ \\
\hline Mutisia spinosa* & $\mathrm{V}$ & - & - & - & - & - & - & - & - & $\mathrm{X}$ \\
\hline Nothofagus pumilio* & $\mathrm{T}$ & - & - & - & - & $\mathrm{X}$ & - & - & - & $\mathrm{X}$ \\
\hline Ozmorhiza chilensis* & $\mathrm{PH}$ & - & - & - & - & - & - & - & - & $\mathrm{X}$ \\
\hline Phacelia secunda* & $\mathrm{PH}$ & - & - & - & - & - & $\mathrm{X}$ & - & - & $\mathrm{X}$ \\
\hline Plagiobothrys verrucosus & $\mathrm{AH}$ & - & - & - & - & - & - & - & $\mathrm{X}$ & $\mathrm{X}$ \\
\hline Ribes magellanicum* & $\mathrm{SH}$ & Yes & $\mathrm{X}$ & - & - & - & - & - & $\mathrm{X}$ & $\mathrm{X}$ \\
\hline Schinus patagonica* & $\mathrm{SH}$ & Yes & - & - & - & - & - & - & - & $\mathrm{X}$ \\
\hline Senecio sp.* & $\mathrm{SH}$ & Yes & - & $\mathrm{X}$ & $\mathrm{X}$ & $\mathrm{X}$ & $\mathrm{X}$ & $\mathrm{X}$ & - & $\mathrm{X}$ \\
\hline Sisyrinchium sp.* & $\mathrm{PH}$ & - & - & - & - & - & - & - & - & $\mathrm{X}$ \\
\hline Solidago chilensis* & $\mathrm{PH}$ & - & - & - & - & $\mathrm{X}$ & $\mathrm{X}$ & & & $\mathrm{X}$ \\
\hline Stipa sp.* & G & - & - & - & $\mathrm{X}$ & - & $\mathrm{X}$ & - & $\mathrm{X}$ & $\mathrm{X}$ \\
\hline Valeriana carnosa* & $\mathrm{PH}$ & - & - & - & - & - & - & - & - & $\mathrm{X}$ \\
\hline Vicia nigricans* & $\mathrm{PH}$ & Yes & $\mathrm{X}$ & $\mathrm{X}$ & $\mathrm{X}$ & $\mathrm{X}$ & $\mathrm{X}$ & $\mathrm{X}$ & $\mathrm{X}$ & $\mathrm{X}$ \\
\hline Exotic & & - & - & - & - & - & - & - & - & - \\
\hline Brassica sp. & $\mathrm{PH}$ & - & $\mathrm{X}$ & - & - & - & - & - & - & - \\
\hline Bromus spp.* & G & - & $\mathrm{X}$ & $\mathrm{X}$ & $\mathrm{X}$ & $\mathrm{X}$ & $\mathrm{X}$ & $\mathrm{X}$ & $\mathrm{X}$ & $\mathrm{X}$ \\
\hline Capsella bursa-pastoris & $\mathrm{AB}$ & - & - & - & - & - & - & - & $\mathrm{X}$ & - \\
\hline Carduus nutans $*$ & $\mathrm{AH}-\mathrm{BH}$ & - & $\mathrm{X}$ & $\mathrm{X}$ & $\mathrm{X}$ & $\mathrm{X}$ & $\mathrm{X}$ & $\mathrm{X}$ & $\mathrm{X}$ & $\mathrm{X}$ \\
\hline Chenopodium album* & $\mathrm{AH}$ & - & - & - & $\mathrm{X}$ & - & - & $\mathrm{X}$ & $\mathrm{X}$ & $\mathrm{X}$ \\
\hline Cirsium vulgare & $\mathrm{BH}$ & - & $\mathrm{X}$ & $\mathrm{X}$ & $\mathrm{X}$ & $\mathrm{X}$ & $\mathrm{X}$ & $\mathrm{X}$ & $\mathrm{X}$ & $\mathrm{X}$ \\
\hline Conyza sp. & $\mathrm{UH}$ & - & - & - & - & - & - & - & $\mathrm{X}$ & - \\
\hline Epilobium paniculatum* & $\mathrm{AH}$ & - & $\mathrm{X}$ & $\mathrm{X}$ & $\mathrm{X}$ & $\mathrm{X}$ & $\mathrm{X}$ & $\mathrm{X}$ & $\mathrm{X}$ & $\mathrm{X}$ \\
\hline Holcus lanatus* & G & - & - & $\mathrm{X}$ & $X$ & - & $\mathrm{X}$ & $\mathrm{X}$ & $\mathrm{X}$ & $\mathrm{X}$ \\
\hline Hordeum comosum & $\mathrm{G}$ & - & $\mathrm{X}$ & $\mathrm{X}$ & $\mathrm{X}$ & $\mathrm{X}$ & $\mathrm{X}$ & $\mathrm{X}$ & - & $\mathrm{X}$ \\
\hline Hypochaeris radicata* & $\mathrm{PH}$ & - & - & - & - & - & - & - & $\mathrm{X}$ & $\mathrm{X}$ \\
\hline Lactuca serriola* & $\mathrm{AH}$ & - & $\mathrm{X}$ & - & $\mathrm{X}$ & $\mathrm{X}$ & - & $\mathrm{X}$ & - & $\mathrm{X}$ \\
\hline Leucanthemum vulgare & $\mathrm{PH}$ & - & - & - & - & - & - & $\mathrm{X}$ & - & - \\
\hline Matricaria matricarioides & $\mathrm{AH}$ & - & - & - & - & - & - & $\mathrm{X}$ & $\mathrm{X}$ & - \\
\hline Taraxacum officinale & $\mathrm{PH}$ & - & - & - & - & - & $\mathrm{X}$ & - & $\mathrm{X}$ & - \\
\hline Verbascum thapsus* & $\mathrm{BH}$ & - & $\mathrm{X}$ & $\mathrm{X}$ & $\mathrm{X}$ & $\mathrm{X}$ & $\mathrm{X}$ & $\mathrm{X}$ & $\mathrm{X}$ & $\mathrm{X}$ \\
\hline
\end{tabular}

References: $\mathrm{S}=$ mineral soil; $\mathrm{LS}=$ litter soil; $-\mathrm{C}=$ control; $-\mathrm{T}=$ tillage; $-\mathrm{TB}=$ tillage and biosolid compost; $\mathrm{SH}=\mathrm{shrub}, \mathrm{T}=$ tree, $\mathrm{AH}=$ annual herb, $\mathrm{BH}=$ biannual herb, $\mathrm{PH}=$ perennial herb, $\mathrm{UH}=$ herb of unknown lifespan, $\mathrm{G}=$ grasses, $\mathrm{V}=$ vine $*=$ fruiting registered; ${ }^{\phi}$ Varela et al. (2006). 